\title{
A Critical Review on Techno-Commercial Study of Reuse of Reclaimed Sand Dust in Brick Manufacturing
}

\author{
Dr. Jayeshkumar Pitroda ${ }^{1}$, Yash G. Gudhka ${ }^{2}$, Ravi M. Kanazariya ${ }^{3}$, \\ Kaushik G.Makwana ${ }^{4}$, Pankaj A. Parmar \\ ${ }^{1}$ Assistant Professor, Civil Engineering Department, B.V.M. Engineering College, Vallabh \\ Vidyanagar-Gujarat-India \\ ${ }^{2,3,4,5}$ Student of final year B.E., Civil Engineering Department, B.V.M Engineering College, Vallabh \\ Vidyanagar-Gujarat-India
}

\begin{abstract}
In the population of industrial era, waste of materials presents many problems. Huge quantity Reclaimed sand dusts in the form of very fine size come out during process of prepare mould for making machinery. As around $75 \%$ waste can be recycled, remaining $25 \%$ waste causing problems of dumping because it do not decay and Damage agriculture land, Drainage, water resources etc. by flying with wind. So it is necessary to find the suitable re-use of this waste. The main aim of this Industry Defined Project (IDP) is to search the possibility of using the Reclaimed sand dust waste in construction industry. This project research work is concerned with the experimental investigation on strength of Bricks and optimum percentage of the partial replacement of Reclaimed sand dust with Fly ash (Class F) and Lime which is to be other alternative of the Clay and Fly ash Bricks. The aim of this research work is to replace the Fly ash (Class F) by Reclaimed sand dust waste accordingly in the range of 0\%, 10\%, 20\%, 30\% 40\% and 50\% by weight.This paper presents the critical literature review on techno-commercial study of reuse of reclaimed sand dust in brick manufacturing.
\end{abstract}

\section{INTRODUCTION}

Brick is an absolutely essential component of construction materials used in infrastructure and most buildings. It is weak in tension and good in compression, little resistance to cracking and has limited ductility. Based on continuous research carried out around the globe, various modifications have been made from time to time to overcome the deficiencies of brick. However, brick is sometimes exposed to substances that can attack it and cause deterioration.

The brick was initially produced by proportion of various resources, forming bricks, and burning the bricks in ancient time. There are the so many modifications in different composition of brick material and different new materials and by-products used in manufacturing of brick and can be changed the property.

Most of the metal industries prefer sand casting system. In this system mould made of uniform sized, high silica sand, clean is used. After casting process foundries recycle and reuse the sand more than one times but after sometime it is discarded from the foundries known as waste foundry sand. The application of waste foundry sand to various engineering sector can solve the problems of its disposal and harmful effect to environment.

\section{LITERATURE REVIEW}

The following are the previous research review based on techno-commercial study of reuse of reclaimed sand dust in brick manufacturing and concrete.

Kadir A. A et al (2002) found that the quantity of waste added into fired clay brick ranged from $1 \%$ to $50 \%$. The advantages by adding the waste sludge is the fibrous nature effect that increased the plasticity increased the porosity after firing thus improved the thermal conductivity properties. At the same time the energy savings are estimated up to $40 \%$ (1) 
Dr Petavratzi Evaggelia et al (2007) stated that the foundry sand can be successively used in bricks as filler at small substitution rates (2.5 and $5 \%$ primary sand substitution.) and also it is envisaged that higher replacement can be feasible. (2)

Salokhe E.P.et al (2012) concluded that the Compressive strength at 7 days of both ferrous and nonferrous mixtures increases as compared to the ordinary mix. Maximum increase was observed with $20 \%$ FWS of both types of sand. However $20 \%$ ferrous WFS addition gives more value of compressive strength than $20 \%$ nonferrous FWS addition. (3)

Zafar Equbal et al. (2012) concluded that the compressive strength of concrete increased with the increases in sand replacement with different replacement levels of foundry sand. However, at each replacement level of fine aggregate with foundry sand, an increase in strength was observed with the increase in age. The compressive strength increased by 5.6\%, 6.7\% and $8.03 \%$ when compared to ordinary mix without foundry sand at 21 days. Compressive strength at 28 days increased by $-8.6 \%$, $5.2 \%$ and $9.8 \%$ compared to ordinary mix. (4)

Patel N.C. et al (2013) concluded that the compressive strength of brick can be increased by using fibre (1\%) upto $5.86 \mathrm{~N} / \mathrm{mm}^{2}$ after 21 days.(5)

Pathariya Saraswati et al (2013) finalized that the foundry sand can be applicable as building material in concrete which results in reduction of $3.5 \%$ of cost for $60 \%$ replacement of waste foundry sand.(6)

Taurino Rosa et al (2015) stated that the low water absorption (1\%), low density $\left(2 \mathrm{~g} / \mathrm{cm}^{3}\right)$ and the good flexural strength (16-20 MPa) were obtained with the addition of 10wt $\%$ of Argalum.(9)

Irani Xerses N. et al (2015) observed that concrete made using foundry waste sand satisfies the compressive strength requirement for M20 and M25 grade concrete at 28 days curing. (7)

Chevuri V.R et al (2015) observed that the compressive strengths were increased with increase in the foundry sand in the concrete mix up to $60 \%$ and will decrease after $60 \%$ up to $100 \%$.The workability of foundry sand increases. The split tensile strengths were increased with increase in the foundry sand in the concrete mix up to $60 \%$ and will decrease after $60 \%$ up to $100 \%$.(10)

Nithiya R.et al (2016)concluded that the bricks are sufficiently hard in $4 \%, 8 \%$ and $12 \%$ replacement of granite waste and the percentage of granite waste increases with increase in the hardness of the brick.(8)

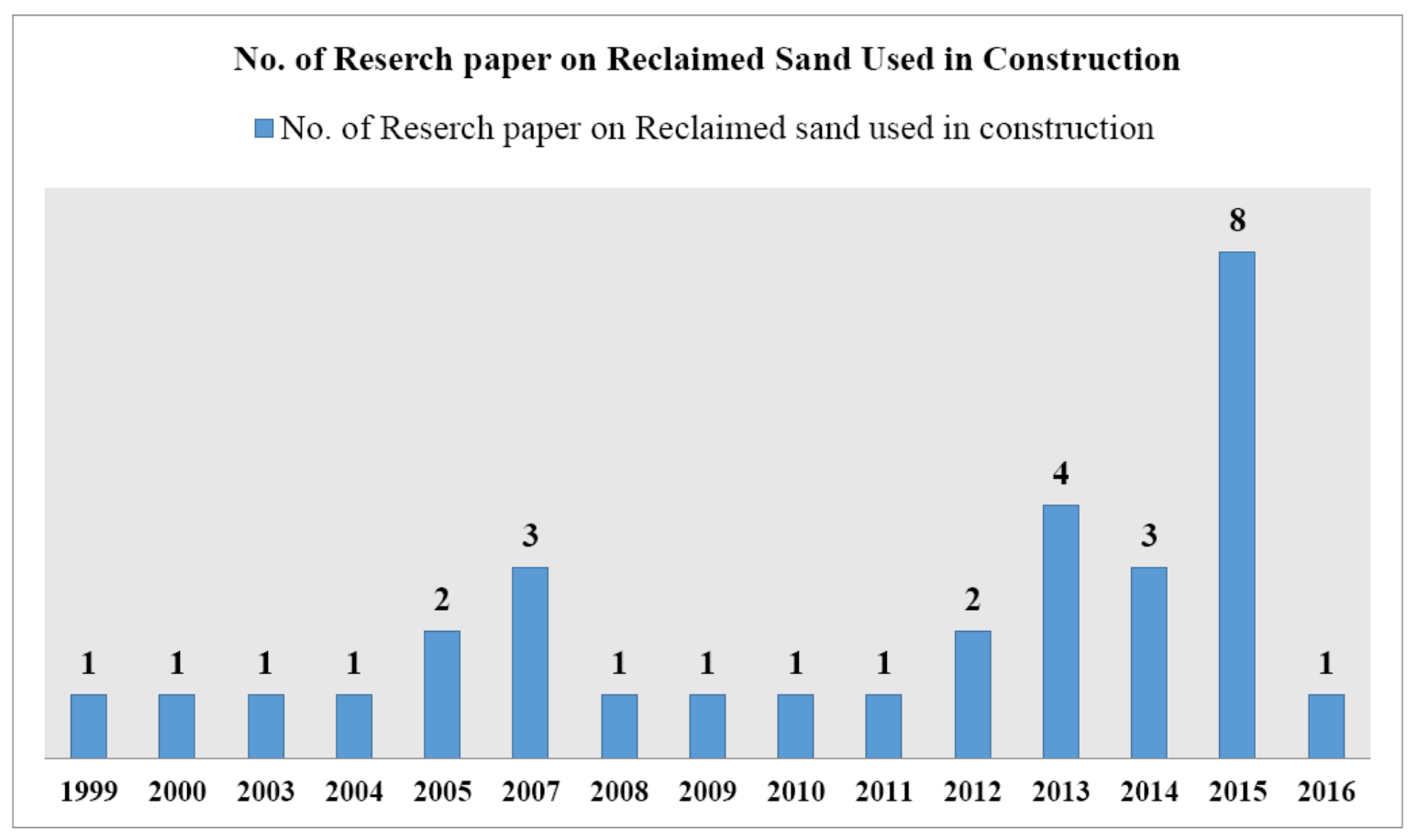

Figure1. Historical Development in the Area of Reclaimed Sand Used in Construction. 


\section{Conclusions}

After completion of its review, Following are the various major finding from the literature reviews.

1. The foundry sand can be applicable as building material in concrete which results in reduction of $3.5 \%$ of cost for $60 \%$ replacement of waste foundry sand.

2. The foundry sand can be successively used in bricks as filler at small substitution rates $(2.5$ and ri5 \% p mary sand substitution.) and also it is envisaged that higher replacement can be feasible.

3. The compressive strength of brick can be increased by using fibre (1\%) upto $5.86 \mathrm{~N} / \mathrm{mm}^{2}$ after 21 days.

4. The low water absorption (1\%), low density $\left(2 \mathrm{~g} / \mathrm{cm}^{3}\right)$ and the good flexural strength (16-20 MPa) were obtained with the addition of $10 \mathrm{wt} \%$ of Argalum.

5. Compressive strength at 7 days of both ferrous \& nonferrous mixtures increases as compared to the ordinary mix. Maximum increase was observed with $20 \%$ FWS of both types of sand. However $20 \%$ ferrous WFS addition gives more value of compressive strength than $20 \%$ nonferrous FWS addition.

6. The quantity of waste added into fired clay brick ranged from $1 \%$ to $50 \%$. The advantages by adding the waste sludge is the fibrous nature effect that increased the plasticity increased the porosity after firing thus improved the thermal conductivity properties. At the same time the energy savings are estimated up to $40 \%$.

7. The bricks are sufficiently hard in $4 \%, 8 \%$ and $12 \%$ replacement of granite waste and the percentage of granite waste increases with increase in the hardness of the brick.

8. Concrete made using foundry waste sand satisfies the compressive strength requirement for M20 and M25 grade concrete at 28 days curing.

9. The compressive strengths were increased with increase in the foundry sand in the concrete mix up to $60 \%$ and will decrease after $60 \%$ up to $100 \%$.The workability of foundry sand increases. The split tensile strengths were increased with increase in the foundry sand in the concrete mix up to $60 \%$ and will decrease after $60 \%$ up to $100 \%$.

10. Compressive strength of concrete increased with the increases in sand replacement with different replacement levels of foundry sand. However, at each replacement level of fine aggregate with foundry sand, an increase in strength was observed with the increase in age. The compressive strength increased by $5.6 \%, 6.7 \%, \& 8.03 \%$ when compared to ordinary mix without foundry sand at 21 days. Compressive strength at 28 days increased by $-8.6 \%, 5.2 \%$ and $9.8 \%$ compared to ordinary mix.

\section{ACKNOWLEDGMENT}

The Authors thankfully acknowledge to Dr. C. L. Patel, Chairman, Charutar Vidya Mandal, and Er. V. M. Patel, Hon. Jt. Secretary, Charutar Vidya Mandal, Prof. (Dr.) Indrajit Patel, Principal, B.V.M. Engineering College, Dr. L. B. Zala, Head and Professor, Civil Engineering Department, Prof. J. J. Bhavsar, Associate Professor, Civil Engineering Department, B.V.M. Engineering College, Vallabh Vidyanagar, Gujarat, India for their motivations and infrastructural support to carry out this research.

\section{REFERENCES}

[1] Aeslina Abdul Kadir, Noor AmiraSarani "An Overview of Wastes Recycling in Fired Clay Bricks" International Journal of Integrated Engineering, 2012.

[2] DrEvaggeliaPetavratzi ,Scott Wilson, "Characterisation of Mineral Wastes, Resources and Processing technologies - Integrated waste management for the production of construction material" case study, November 2007.

[3] EknathP.Salokhe, D.B.Desai, "Application of Foundry Waste Sand in Manufacture of Concrete" IOSR Journal of Mechanical and Civil Engineering 2012.

[4] Md.ZafarEqubal, T.P. Meikandaan, "Strength Behaviour of Foundry sand Used in High Strength Concrete" International Journal of Computer \& Organization Trends, Aug 2012. 
[5] Nutan C. Patel1, Prof. Jayeshkumar Pitroda, "Fly ash brick: glass fibre the Innovative concept for getting higher strength brick" International Journal of Innovative Research in Science, Engineering and Technology,March 2013.

[6] PathariyaSaraswati, Rana Jaykrushna, Shah Palas, Mehta Jay, "Application of Waste Foundry Sand for Evolution of Low-Cost Concrete" International Journal of Engineering Trends and Technology (IJETT), October 2013.

[7] Raghavendra K, Virendra Kumara. K. N, "Reusing of Glass Powder and Industrial Waste Materials in Concrete" International Journal of Research in Engineering and Technology, July2015.

[8] R.Nithiya ,ChrisAnto.L, K.R.Vinodh, Dr.C.Anbalagan, "Experimental Investigation on Bricks By Using Various Waste Materials" international journals of latest trend in engineering and technology ,January 2016.

[9] Rosa Taurino, Fernanda Andreola, Cristina Leonelli, "Physical-Mechanical Properties of New Green Building Materials Based On Glass Waste" Environmental Engineering and Management Journal, 2015.

[10] Vema Reddy Chevuri, S.Sridhar, "Usage of Waste Foundry Sand in Concrete" SSRG International Journal of Civil Engineering (SSRG-IJCE), December 2015.

\section{AUTHORS' BIOGRAPHY}

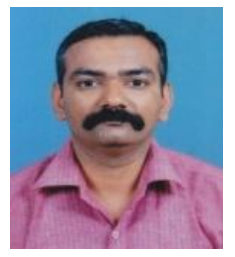

Dr. Jayeshkumar Pitroda, received his Bachelor of Engineering Degree in Civil Engineering from Birla Vishwakarma Mahavidyalaya Engineering College, Sardar Patel University in 2000. In 2009 he received his master's degree in Construction Engineering and Management form Birla Vishwakarma Mahavidyalaya Sardar Patel University. In 2015 he received his Doctor of Philosophy (Ph.D.) Degree in Civil Engineering from Sardar Patel University. He joined Birla Vishwakarma Mahavidyalaya Engineering College as a faculty in 2009, where he is Assistant Professor of Civil Engineering Department with a total experience of 16 years in the field of Research, Designing and Education. He is guiding M.E. / M.Tech (Construction Engineering and Management) thesis work in the field of Civil / Construction Engineering. He has published many papers in National / International Conferences and International Journals. He has published seven Research Books in the field of Civil Engineering, Rural Road Construction, National Highways Construction, Utilization of Industrial Waste, Fly Ash Bricks, Construction Engineering and Management, Eco-friendly Construction.

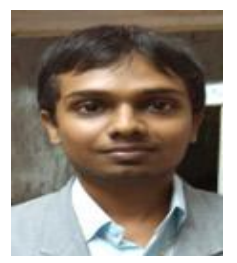

YashGadhaka, is student of final year, B.E. Civil Engineering., Study in BVM Engineering College, Vallabh Vidyanagar, Gujarat, India.

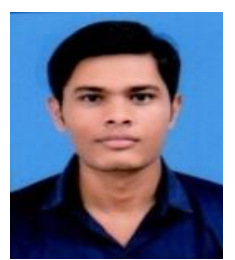

Ravi M. Kanazariya, is student of final year, B.E. Civil Engineering., Study in BVM Engineering College, Vallabh Vidyanagar, Gujarat, India.

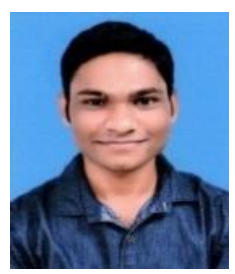

KaushikG.Makwana, is student of final year, B.E. Civil Engineering., Study in BVM Engineering College, Vallabh Vidyanagar, Gujarat, India.

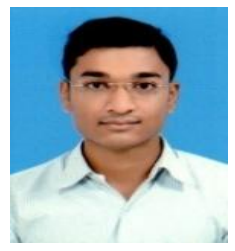

Pankaj Parmar, is student of final year, B.E. Civil Engineering., Study in BVM Engineering College, Vallabh Vidyanagar, Gujarat, India. 